Buletin Ilmiah Math. Stat. dan Terapannya (Bimaster)

Volume 08, No.3 (2019), hal 477-484.

\title{
MODEL MULTI STATUS DALAM PENENTUAN ASURANSI KESEHATAN PENDERITA PENYAKIT JANTUNG
}

\author{
Nurmaulia Ningsih, Neva Satyahadewi, Hendra Perdana
}

\begin{abstract}
INTISARI
Asuransi merupakan suatu lembaga keuangan, tetapi bukan bank yang memberikan perlindungan atas kerugian. Asuransi Long Term Care (LTC) merupakan asuransi yang menyediakan santunan (manfaat) bagi tertanggung yang membutuhkan perawatan medis atau para penderita penyakit kronis maupun cacat tubuh yang tidak bisa dijaminkan pada asuransi lain. Penelitian ini membahas tentang perhitungan premi untuk asuransi LTC produk Annuity as A Rider Benefit dengan model multi status (tiga status). Tiga status yang digunakan yaitu status sehat, status sakit dan status meninggal. Perhitungan premi berdasarkan matriks peluang transisi dengan data tingkat prevalensi penyakit jantung di Indonesia tahun 2013. Studi kasus yang digunakan dalam penelitian ini yaitu seorang pria berusia 30 tahun mengikuti asuransi LTC dengan masa tanggungan 5 tahun. Diketahui bahwa nilai santunan ketika seseorang tersebut mengalami kematian sebesar Rp100.000.000 dan jika seseorang mengalami masa perawatan sebesar Rp20.000.000 setiap tahun masa tertanggung. Suku bunga yang digunakan yaitu 5\% berdasarkan BI Rate. Hasil perhitungan diperoleh premi tahunan untuk asuransi LTC dengan produk Annuity as A Rider Benefit adalah Rp6.037.148. Kemudian Nilai suku bunga yang dipilih berpengaruh terhadap nilai pembayaran premi tahunan asuransi. Semakin besar nilai tingkat suku bunga maka semakin kecil nilai premi tunggal asuransi.
\end{abstract}

Kata Kunci: Long Term Care, Model Multi Status.

\section{PENDAHULUAN}

Asuransi merupakan lembaga keuangan yang memberikan perlindungan atas kerugian keuangan yang disebabkan oleh peristiwa yang tidak terduga [1]. Salah satu kegiatan dalam asuransi ialah pembayaran premi. Premi asuransi adalah pembayaran dari tertanggung pada penanggung sebagai imbalan jasa atas jaminan perlindungan yang diberikan oleh penanggung. Premi ada dua macam yaitu premi bersih (netto) dan premi kotor (bruto) [2]. Perhitungan premi bersih dalam asuransi kesehatan dapat dilakukan dengan menggunakan model perhitungan stokastik. Jika perhitungan mengandung variable acak (hanya berdasarkan peluang) maka dikatakan model stokastik. Perhitungan dengan model stokastik dapat dilakukan dengan asumsi rantai Markov [2].

Berbagai penelitian dilakukan untuk mengembangkan ilmu aktuaria, khususnya untuk asuransi kesehatan. Pada prinsipnya, perhitungan asuransi kesehatan didasarkan pada model multi status [3]. Asuransi kesehatan dapat memberi pertanggungan jika tertanggung mengalami keadaan sakit atau disabilitas dan memberikan sejumlah manfaat. Rantai Markov sangat dibutuhkan untuk menghitung peluang terjadinya transisi dari satu status ke status yang lainnya saat tertanggung meninggal dunia sesuai dengan perjanjian yang tertulis pada polis [4]. Salah satu produk model multi status dengan asuransi kesehatan LTC yaitu Annuity as A Rider Benefit. Asuransi LTC merupakan asuransi kesehatan yang diperuntukan untuk tertanggung yang mengalami riwayat penyakit kronis. Dalam asuransi kesehatan LTC terdapat salah satu produk pembayaran premi yaitu Annuity as A Rider Benefit. Produk tersebut memberikan sejumlah santunan perawatan medis selama jangka waktu tertentu dan santunan kematian apabila tertanggung meninggal dunia. Produk ini tidak ada transisi dari status sakit ke status sehat (tidak ada asumsi tertanggung mengalami kesembuhan).

Penelitian ini bertujuan untuk menentukan model multi status pada asuransi kesehatan LTC. Menentukan Matriks transisi untuk membuat suatu status yang dapat berpindah-pindah ke status lainnya. Dan menentukan besaran premi yang ditentukan pada produk dari asuransi kesehatan LTC yaitu Annuity as A Rider Benefit. Perhitungan premi yang tepat dibutuhkan agar perusahaan asuransi dapat menjamin pembayaran klaim dan santunan tanpa mengalami kerugian. Data yang digunakan adalah data tingkat 
prevalensi penyakit jantung di Indonesia tahun 2013. Perhitungan premi asuransi kesehatan LTC dimulai dengan memasukkan TMI tahun 2011, menghitung data tingkat prevalensi penyakit jantung dengan menggunakan interpolasi linear. Membentuk model multi status dari data tingkat prevalensi penyakit jantung yang telah diinterpolasi. Setelah membentuk model dilanjutkan dengan penyusunan matriks yang disertai dengan menentukan usia tertanggung, masa perawatan, besaran santunan yang akan diberikan dan menentukan tingkat suku bunga. Kemudian berdasarkan informasi tersebut dicari nilai premi bersih dari asuransi kesehatan LTC pada produk Annuity as A Rider Benefit.

\section{INTERPOLASI LINEAR}

Interpolasi adalah proses pencarian dan penghitungan nilai suatu fungsi yang grafiknya melewati sekumpulan titik yang diberikan. Titik-titik tersebut mungkin merupakan hasil sebuah percobaan atau diperoleh dari suatu fungsi diketahui. Interpolasi linier adalah cara menentukan nilai yang berada diantara dua nilai diketahui berdasarkan persamaan linier (persamaan garis lurus).

Persamaan garis lurus yang melalui dua titik $P_{1}\left(x_{1}, y_{1}\right)$ dan $P_{2}\left(x_{2}, y_{2}\right)$ dapat dituliskan dengan:

$$
y=\frac{y_{2}-y_{1}}{x_{2}-x_{1}}\left(x-x_{1}\right)+y_{1}
$$

Perbandingan jarak $\left(y-y_{1}\right)$ dengan jarak $\left(y_{2}-y_{1}\right)$ sama dengan perbandingan jarak $\left(x-x_{1}\right)$ dengan jarak $\left(x_{2}-x_{1}\right)$. Interpolasi dilakukan untuk mendapatkan tingkat prevalensi secara spesifik untuk tiap umur dalam kelompok.

\section{ASURANSI LONG TERM CARE (LTC)}

Asuransi Long Term Care (LTC) adalah asuransi perawatan yang diperlukan sehubungan dengan kondisi penyakit kronis [5]. Asuransi LTC memberikan dukungan pendapatan bagi tertanggung yang membutuhkan perawatan medis dalam bentuk manfaat anuitas atau pengembalian biaya pengobatan dan perawatan. Sebuah asuransi LTC tertentu juga mencakup anuitas hidup dalam kasus annuitant menjadi cacat.

Asuransi LTC dipengaruhi oleh beberapa jenis risiko, dengan mengabaikan risiko investasi yang menyangkut produk di daerah asuransi orang lain. Perusahaan asuransi hanya berkonsentrasi pada risiko yang berasal dari morbiditas dan durasi kehidupan (panjang umur). Manfaat asuransi LTC dapat dikelompokkan menjadi tiga kategori, sebagai berikut:

1. Sejumlah manfaat yang berbentuk anuitas yang ditawarkan bagi orang sehat.

2. Sejumlah manfaat yang berbentuk anuitas yang ditawarkan bagi orang lanjut usia pada waktu akan memasuki atau sedang memasuki masa perawatan.

3. Pembayaran kembali biaya perawatan dan pengobatan.

\section{MODEL MULTI STATUS}

Model multi status (multi state models) pada aktuaria merupakan alat yang paling efektif untuk digunakan dalam penafsiran (actuarial forecasting), khususnya pada asuransi kesehatan. Model multi status adalah model yang digunakan untuk proses stokastik di mana seseorang dapat berpindah pada sejumlah status yang terbatas [6]. Perubahan atau perpindahan status yang ditempati seseorang dinamakan transisi atau kejadian. Kompleks dari suatu model multi status sangat tergantung pada jumlah status di dalam model dan kemungkinan transisi antar status. Salah satu bentuk model multi status sederhana adalah model sakit-meninggal (illness-death model) dengan tiga status yaitu sehat, sakit dan meninggal, seperti pada Gambar 1: 


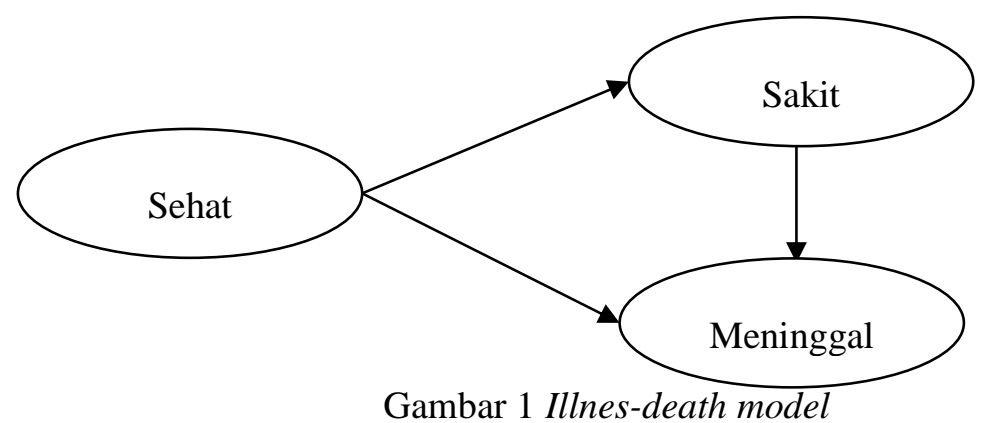

Asuransi Long Term Care (LTC) dimodelkan dalam kerangka multi status. Keadaan kesehatan seseorang baik itu sakit maupun sehat dipandang sebagai suatu status. Seseorang yang berada pada status awal dalam keadaan sehat dapat berpindah ke status sakit ataupun status meninggal (Gambar 1). Seseorang yang berada status sakit tetap tidak bisa lagi kembali ke status sebelumnya (sehat). Seseorang yang berada pada status tertentu hanya dapat berpindah ke status yang lebih tinggi. Misalnya seseorang dengan status sehat hanya dapat bertransisi ke status sakit atau meninggal, sedangkan status sakit hanya bisa pindah ke status meninggal dan tidak bisa lagi kembali ke status sehat.

\section{PELUANG UNTUK MODEL WAKTU DIKRET}

Dinotasikan $x$ sebagai usia tertanggung saat perjanjian polis dan $s(x)$ sebagai fungsi survival pada rantai Markov diskret. Didefinisikan tiga status yaitu : kejadian sehat, kejadian sakit kejadian meninggal. Ilustrasi model tiga status dapat digambarkan sebagai berikut:

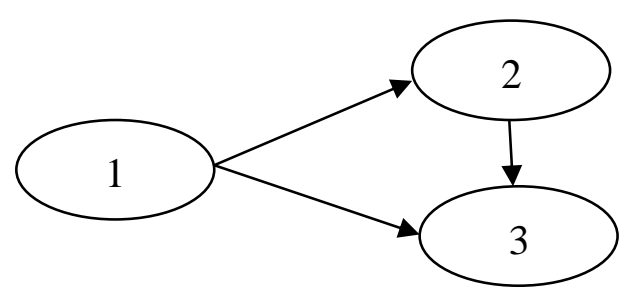

Gambar 2. Diagram model tiga status

Dari Gambar 2 diatas dibentuk menjadi sebuah matriks ordo $3 \times 3$ seperti berikut:

$$
\mathbf{P}_{x}=\left[\begin{array}{ccc}
p_{x}^{11} & p_{x}^{12} & q_{x}^{1} \\
0 & p_{x}^{22} & q_{x}^{2} \\
0 & 0 & 1
\end{array}\right]
$$

Keterangan:

$p_{x}^{11}=$ nilai peluang seseorang berusia $x$ tahun yang saat ini dalam keadaan sehat akan tetap dalam keadaan sehat di waktu berikutnya

$p_{x}^{12}=$ nilai peluang seseorang berusia $x$ tahun yang saat ini dalam keadaan sehat akan dalam keadaan sakit di waktu berikutnya

$p_{x}^{22}=$ nilai peluang seseorang berusia $x$ tahun yang saat ini dalam keadaan sakit akan tetap dalam keadaan sakit di waktu berikutnya

$q_{x}^{1}=$ nilai peluang seseorang berusia $x$ tahun yang saat ini dalam keadaan sehat akan dalam keadaan meninggal di waktu berikutnya

$q_{x}^{2}=$ nilai peluang seseorang berusia $x$ tahun yang saat ini dalam keadaan sakit akan dalam keadaan meninggal di waktu berikutnya

Peluang transisi $h$ langkah berdasarkan rantai Markov dapat dituliskan dalam Persamaan (2), yaitu: 


$$
{ }_{h} \mathbf{P}_{x}=\left[\begin{array}{ccc}
p_{x}^{11} & p_{x}^{12} & q_{x}^{1} \\
0 & p_{x}^{22} & q_{x}^{2} \\
0 & 0 & 1
\end{array}\right] \cdot\left[\begin{array}{ccc}
p_{x+1}^{11} & p_{x+1}^{12} & q_{x+1}^{1} \\
0 & p_{x+1}^{22} & q_{x+1}^{2} \\
0 & 0 & 1
\end{array}\right] \cdots\left[\begin{array}{ccc}
p_{x+h-1}^{11} & p_{x+h-1}^{12} & q_{x+h-1}^{2} \\
0 & p_{x+h-1}^{22} & q_{x+h-1}^{2} \\
0 & 0 & 1
\end{array}\right]
$$

\section{PRODUK ANNUITY AS A RIDER BENEFIT}

Annuity as A Rider Benefit, merupakan salah satu produk dari asuransi Long Term Care yang menyediakan manfaat biaya perawatan medis selama jangka waktu dan manfaat kematian apabila pihak tertanggung meninggal, baik meninggal karena penyakit yang dideritanya, maupun meninggal tanpa mengalami sakit yang terlebih dahulu. Dalam produk Annuity as A Rider Benefit tidak ada transisi dari status sakit ke status sehat (tidak adanya asumsi mengalami kesembuhan), seperti digambarkan pada Gambar 1.

Dari model tiga status, dinotasikan $c$ sebagai manfaat kematian yaitu sejumlah uang yang diberikan ketika tertanggung meninggal dunia. Dinotasikan pula $b$ sebagai pembayaran tahunan yaitu manfaat yang dibayarkan rutin setiap tahun apabila tertanggung mengalami masa perawatan. Diasumsikan $b=\frac{c}{r}$, dimana $r$ adalah nilai maksimum dari waktu pembayaran anuitas manfaat (dalam tahunan) apabila tanggungan dalam masa perawatan. Apabila tanggungan mengalami masa perawatan sebelum meninggal dunia, didefinisikan manfaat kematian sebagai $c_{i}(t)=c-b \min (h, r)$ dimana $h$ sebagai lama waktu pembayaran anuitas manfaat saat tertanggung dalam masa perawatan hingga meninggal dunia. Nilai premi tunggal bersih asuransi tersebut adalah:

$$
\left.A_{x \cdot \bar{n}}^{L T C}=c \sum_{e=1}^{n} v^{e}\left(_{e-1} p_{x}^{11}\right)\left(q_{x+e-1}^{1}\right)+b \sum_{e=1}^{n} v^{e}\left({ }_{e-1} p_{x}^{11}\right)\left(p_{x+e-1}^{12}\right) \ddot{a}_{x+e \cdot 7}^{22}+\sum_{e=1}^{n} v^{e}\left({ }_{e-1} p_{x}^{11}\right)\left(p_{x+e-1}^{12}\right) \sum_{h=1}^{\frac{c}{b}}(c-h b) v^{h}{ }_{h-1} p_{x+e}^{22}\right)\left(q_{x+e+h-1}^{2}\right)
$$

Diasumsikan premi dibayarkan setiap awal tahun selama $n$ tahun ketika tertanggung masih dalam keadaan sehat. Nilai premi asuransi tersebut adalah:

$$
P=\frac{A_{x: n}^{L T C}}{\ddot{a}_{x: n}^{i j}}
$$

\section{STUDI KASUS}

Data tingkat prevalensi yang digunakan adalah data riset kesehatan dasar yang diperoleh tahun 2013. Data tersebut terdiri dari tiga jenis penyakit jantung yaitu jantung koroner, gagal jantung dan stroke. Data riset tersebut dapat dilihat pada Tabel 1, sebagai berikut:

Tabel 1 Data Prevalensi Penderita Penyakit Jantung

\begin{tabular}{|r|l|r|r|r|r|r|r|r|}
\hline \multirow{2}{*}{ No } & Jenis Penderita & \multicolumn{6}{|c|}{ Tingkat Prevalensi dalam (\%) kelompok umur } \\
\cline { 3 - 10 } & $\begin{array}{c}\text { Penyakit } \\
\text { Jantung }\end{array}$ & $\mathbf{1 5 - 2 4}$ & $\mathbf{2 5 - 3 4}$ & $\mathbf{3 5 - 4 4}$ & $\mathbf{4 5 - 5 4}$ & $\mathbf{5 5 - 6 4}$ & $\mathbf{6 5 - 7 4}$ & $\mathbf{7 5 +}$ \\
\hline 1 & Jantung Koroner & 0,7 & $\mathbf{\%}$ & $\mathbf{\%}$ & $\boldsymbol{\%}$ & $\boldsymbol{\%}$ & $\boldsymbol{\%}$ & $\boldsymbol{\%}$ \\
\hline 2 & Gagal Jantung & 0,1 & 0,1 & 1,3 & 2,1 & 2,8 & 3,5 & 3,2 \\
\hline 3 & Stroke & 2,6 & 3,9 & 6,4 & 16,7 & 33 & 46,1 & 67 \\
\hline
\end{tabular}

Sumber: www.kemkes.go.id

Berdasarkan Tabel 1 maka ditentukan nilai hasil interpolasi dalam setiap umur penderita penyakit jantung dengan menggunakan rumus interpolasi pada Persamaan (1). Misalkan ingin mengetahui tingkat prevalensi penderita penyakit jantung $(y)$ seseorang pada umur $(x) 16$ tahun, maka perhitungannya adalah:

$x=16$ tahun $\quad x_{1}=15$ tahun $\quad x_{2}=25$ tahun 
$y=$ hasil tingkat prevalensi penderita penyakit jantung umur 16 tahun.

$y_{1}=$ tingkat prevalensi penderita penyakit jantung umur 15-24 tahun

$y_{2}=$ tingkat prevalensi penderita penyakit jantung umur 25-34 tahun

Sehingga diperoleh nilai tingkat prevalensi berdasarkan jenis penyakit jantung pada usia 16 tahun, yaitu:

1. Tingkat prevalensi penderita penyakit jantung koroner

$$
\begin{aligned}
y & =\frac{y_{2}-y_{1}}{x_{2}-x_{1}}\left(x-x_{1}\right)+y_{1} \\
& =\frac{0,009-0,007}{25-15}(16-15)+0,007 \\
& =0,0072 \\
& =0,72 \%
\end{aligned}
$$

2. Tingkat prevalensi penderita penyakit gagal jantung

$$
\begin{aligned}
y & =\frac{y_{2}-y_{1}}{x_{2}-x_{1}}\left(x-x_{1}\right)+y_{1} \\
& =\frac{0,001-0,001}{25-15}(16-15)+0,001 \\
& =0,001 \\
& =0,1 \%
\end{aligned}
$$

3. Tingkat prevalensi penderita penyakit stroke

$$
\begin{aligned}
y & =\frac{y_{2}-y_{1}}{x_{2}-x_{1}}\left(x-x_{1}\right)+y_{1} \\
& =\frac{0,039-0,026}{25-15}(16-15)+0,039 \\
& =0,0273 \\
& =2,73 \%
\end{aligned}
$$

Perhitungan dilakukan dengan cara yang sama untuk tingkat umur berikutnya, sehingga didapatkan hasil interpolasi pada Tabel 2 sebagai berikut:

Tabel 2. Hasil persentase interpolasi linear tingkat prevalensi penyakit jantung

\begin{tabular}{|c|c|c|c|c|}
\hline \multicolumn{5}{|c|}{ Jenis Penderita Penyakit Jantung (\%) } \\
\hline Umur & Jantung Koroner & Gagal Jantung & Stroke & Total \\
\hline 15 & 0,70 & 0,10 & 2,60 & 3,40 \\
\hline 16 & 0,72 & 0,10 & 2,73 & 3,55 \\
\hline 17 & 0.74 & 0.10 & 2.86 & 3.70 \\
\hline$\vdots$ & $\vdots$ & $\vdots$ & $\vdots$ & $\vdots$ \\
\hline 30 & 1,10 & 0,15 & 5,15 & 6.40 \\
\hline 31 & 1,14 & 0,16 & 5,40 & 6,70 \\
\hline 32 & 1,18 & 0,17 & 5,65 & 7,00 \\
\hline$\vdots$ & $\vdots$ & $\vdots$ & $\vdots$ & $\vdots$ \\
\hline 74 & 3,23 & 1,08 & 64,91 & 69,22 \\
\hline 75 & 3,20 & 1,10 & 67,00 & 71,30 \\
\hline
\end{tabular}

\section{PENYUSUNAN MATRIKS TRANSISI}

Pada kasus penelitian ini digunakan transisi satu arah, misalkan transisi dari status sehat ke status sakit, namun tidak ada transisi dari status sakit ke status sehat (tidak ada keadaan sembuh). Adapun matriks peluang transisi $h$ langkah dengan tiga status menggunakan Persamaan (3), yaitu: 
dengan:

$$
{ }_{h} \mathbf{p}_{x}=\left[\begin{array}{ccc}
p_{x}^{11} & p_{x}^{12} & q_{x}^{1} \\
0 & p_{x}^{22} & q_{x}^{2} \\
0 & 0 & 1
\end{array}\right] \cdot\left[\begin{array}{ccc}
p_{x+1}^{11} & p_{x+1}^{12} & q_{x+1}^{1} \\
0 & p_{x+1}^{22} & q_{x+1}^{2} \\
0 & 0 & 1
\end{array}\right] \ldots\left[\begin{array}{ccc}
p_{x+h-1}^{11} & p_{x+h-1}^{12} & q_{x+h-1}^{1} \\
0 & p_{x+h-1}^{22} & q_{x+h-1}^{2} \\
0 & 0 & 1
\end{array}\right]
$$

$$
\begin{aligned}
& p_{x}^{11}=1-p_{x}^{12}-q_{x}^{1} \\
& q_{x}^{2}=(1+\eta) \times q_{x}^{1}, \eta \geq 0 \\
& p_{x}^{22}=1-q_{x}^{2}
\end{aligned}
$$

Misalkan seorang pria berumur 30 Tahun, perhitungan matriks peluang transisi satu langkah dari seorang pria umur 30 tahun yaitu:

1. Peluang meninggal $\left(q_{x}^{1}\right)$ seseorang berusia 30 tahun satu tahun kemudian, yaitu $q_{30}^{1}=0,0008$ nilai ini di dapat pada tabel mortalita indonesia 2011 umur 30 tahun.

2. Peluang seorang pria berusia 30 tahun pada keadaan status sehat (1) menjadi status menderita penyakit jantung (2) satu tahun kemudian, yaitu $p_{30}^{12}=0,0640$.

3. Peluang seorang pria berusia 30 tahun dalam keadaan sehat menjadi tetap dalam kondisi sehat satu tahun kemudian, yaitu:

$$
\begin{aligned}
p_{x}^{11} & =1-\left(p_{x}^{12}+q_{x}^{1}\right) \\
p_{30}^{11} & =1-(0,0640+0,0008) \\
& =0,9352
\end{aligned}
$$

4. Peluang meninggal seorang pria berusia 30 tahun penderita penyakit jantung satu tahun kemudian dengan nilai konstanta pembanding $\eta=0,05$, yaitu:

$$
\begin{aligned}
q_{x}^{2} & =(1+\eta) \times q_{x}^{1} ; \eta=0,05 \\
q_{30}^{2} & =(1+0,05) \times 0,0008 \\
& =0,0008
\end{aligned}
$$

5. Peluang seorang pria berumur 30 tahun yang menderita penyakit jantung menjadi tetap dalam keadaan sakit jantung satu tahun kemudian, yaitu:

$$
\begin{aligned}
p_{x}^{22} & =1-q_{x}^{2} \\
p_{30}^{22} & =1-0,0008 \\
& =0,9992
\end{aligned}
$$

Sehingga diperoleh matriks peluang transisi satu langkah berikut:

$$
\mathbf{P}_{30}=\left[\begin{array}{ccc}
0,9352 & 0,0640 & 0,0008 \\
0 & 0,9992 & 0,0008 \\
0 & 0 & 1
\end{array}\right]
$$

Matriks peluang transisi satu langkah dapat digambarkan dalam diagram:

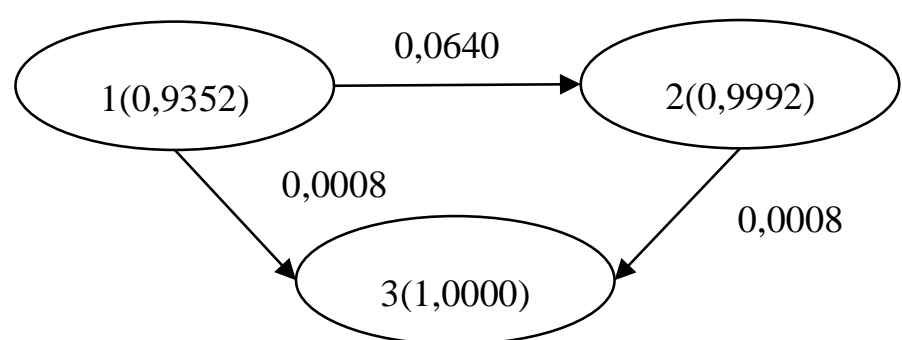

Gambar 4. Diagram transisi satu langkah untuk seorang pria 30 tahun 
Selanjutnya untuk perhitungan matriks peluang transisi $h$ langkah untuk seorang berumur 30 tahun diperoleh dengan melakukan perkalian matriks dimana $h=1,2,3,4,5$. Perkalian matriks diambil 5 kali langkah transisi, matriks peluang transisi 5 langkah sebagai berikut:

$$
\begin{array}{ll}
{ }_{1} \mathbf{P}_{30}=\left[\begin{array}{ccc}
0,93520 & 0,06400 & 0,00080 \\
0 & 0,99992 & 0,00008 \\
0 & 0 & 1
\end{array}\right] & { }_{2} \mathbf{P}_{30}=\left[\begin{array}{ccc}
0,87184 & 0,12660 & 0,00156 \\
0 & 0,99836 & 0,00164 \\
0 & 0 & 1
\end{array}\right] \\
{ }_{3} \mathbf{P}_{30}=\left[\begin{array}{ccc}
0,81011 & 0,18750 & 0,00239 \\
0 & 0,99749 & 0,00251 \\
0 & 0 & 1
\end{array}\right] & { }_{4} \mathbf{P}_{30}=\left[\begin{array}{ccc}
0,75026 & 0,24650 & 0,00324 \\
0 & 0,99661 & 0,00339 \\
0 & 0 & 1
\end{array}\right] \\
{ }_{5} \mathbf{P}_{30}=\left[\begin{array}{ccc}
0,69259 & 0,30330 & 0,00411 \\
0 & 0,99571 & 0,00429 \\
0 & 0 & 1
\end{array}\right] &
\end{array}
$$

\section{PERHITUNGAN PREMI ASURANSI LONG TERM CARE}

Pada penelitian ini, diambil kasus perhitungan nilai premi bersih asuransi dari seseorang yang mengikuti asuransi LTC pada produk Annuity as A Rider Benefit pada umur 30 tahun, dengan santunan sebesar Rp100.000.000,- apabila meninggal dunia. Tertanggung juga menginginkan sejumlah manfaat lainnya berupa pembayaran anuitas selama maksimal 5 tahun apabila menjalani perawatan (status 2). Premi dibayarkan tiap awal tahun selama 5 tahun selama tertanggung dalam keadaan sehat (status 1). Tingkat suku bunga yang digunakan sebesar $5 \%$. Sehingga dihitung besarnya premi tahunan yang harus dibayarkan tertanggung selama masa perjanjian untuk mendapatkan manfaat sesuai dengan perjanjian. Berdasarkan Persamaan (3) maka perhitungan premi tunggal asuransi adalah sebagai berikut:

$$
\begin{aligned}
A_{x: \bar{n}}^{L T C} & \left.=c \sum_{e=1}^{n} v^{e}\left({ }_{e-1} p_{x}^{11}\right)\left(q_{x+e-1}^{1}\right)+b \sum_{e=1}^{n} v^{e}\left({ }_{e-1} p_{x}^{11}\right)\left(p_{x+e-1}^{12}\right) \ddot{a}_{x+e \cdot 7 T}^{22}+\sum_{e=1}^{n} v^{e}\left({ }_{e-1} p_{x}^{11}\right)\left(p_{x+e-1}^{12}\right) \sum_{h=1}^{\frac{c}{b}}(c-h b) v^{h}{ }_{h-1} p_{x+e}^{22}\right)\left(q_{x+e+h-1}^{2}\right) \\
A_{30: 51}^{L T C} & =R p 27.259 .534,364
\end{aligned}
$$

Sehingga premi tunggal asuransi kesehatan Long Term Care dengan produk Annuity as A Rider Benefit untuk seorang berusia 30 tahun jangka waktu asuransi selama 5 tahun yaitu sebesa $R p 27.259 .534$. Perhitungan premi tahunan dalam hal ini membutuhkan nilai anuitas, dimana anuitas yang digunakan adalah anuitas awal. Berdasarkan Persamaan (4) diperoleh nilai anuitas, yaitu:

$$
\begin{array}{ll}
P\left(A_{30: 55}^{L T C}\right) & =\frac{A_{30: 55}^{L C T}}{\sum_{h=0}^{5} v^{h}{ }_{h} p_{30}^{11}} \\
P\left(A_{30: 55}^{L T C}\right) & =\frac{27259534,364}{4,5153} \\
P\left(A_{30: 55}^{L T C}\right) & =R p 6.037 .148
\end{array}
$$

Pada Tabel 3 dapat dilihat perhitungan premi bersih tahunan asuransi ini juga dihitung dengan berbagai nilai $i$ (suku bunga) bervariasi dan masa pertanggungan asuransi yang berbeda. Suku bunga yang digunakan yaitu 5\%,7.5\% dan 10\%, sedangkan masa pertanggungan asuransi yaitu 5, 10, 15 dan 20 tahun.

Tabel 3. Perbandingan nilai premi bersih tahunan

\begin{tabular}{|c|c|c|c|c|c|}
\hline \multicolumn{7}{|c|}{ Premi bersih tahunan } \\
\hline Umur & $\begin{array}{c}\text { Suku } \\
\text { Bunga }\end{array}$ & $\mathbf{5}$ tahun & $\mathbf{1 0}$ tahun & $\mathbf{1 5}$ tahun & $\mathbf{2 0}$ tahun \\
\hline \multirow{2}{*}{$\begin{array}{c}\text { 30 } \\
\text { Tahun }\end{array}$} & $5 \%$ & Rp6.037.148 & Rp3.384.951 & Rp2.518.265 & Rp2.097.356 \\
\cline { 2 - 6 } & $\mathbf{7 . 5 \%}$ & Rp5.776.148 & Rp3.404.674 & Rp2.647518 & Rp2.292.356 \\
\cline { 2 - 6 } & $\mathbf{1 0 \%}$ & Rp5.538.155 & Rp 3.416.671 & Rp2.760.156 & Rp2.465.943 \\
\hline
\end{tabular}


Berdasarkan Tabel 3 menunjukkan bahwa pada umur 30 tahun saat memulai asuransi, terjadi penurunan nilai premi bersih tahunan seiring bertambahnya masa pembayaran premi $(r)$. Nilai suku bunga $(i)$ yang dipilih juga sangat berpengaruh terhadap nilai pembayaran premi tahunan asuransi karena semakin besar nilai tingkat suku bunga maka nilai pembayaran premi semakin kecil.

\section{PENUTUP}

Berdasarkan hasil dan pembahasan dalam skripsi ini maka dapat disimpulkan bahwa perhitungan premi bersih tahunan asuransi Long Term Care pada produk Annuity as A Rider Benefit yang ditentukan berdasarkan fungsi peluang transisi rantai Markov adalah:

1. Perhitungan premi asuransi LTC dihitung berdasarkan peluang transisi rantai Markov dari keadaan sehat ke keadaan sakit, dari keadaan sehat ke keadaan meninggal, dan dari keadaan sakit ke keadaan meninggal.

2. Nilai premi bersih tahunan yang harus dibayarkan tertanggung kepada penanggung meningkat seiring bertambahnya usia awal saat mengikuti asuransi LTC, untuk umur 30 tahun sebesar Rp6.037.148,-.

3. Kenaikan tingkat bunga dari $\mathrm{i}=5 \%, 7,5 \%$ dan $10 \%$ akan meyebabkan turunnya nilai premi bersih tahunan yang harus dibayarkan tertanggung kepada penanggung.

\section{DAFTAR PUSTAKA}

[1] Zahra, N. Perhitungan Modifikasi Cadangan Premi Pada Asuransi Jiwa Seumur Hidup Menggunakan Metode Fackler. Jurnal vol. 2. No 3. Pages 200-203. Jurnal Mahasiswa Matematika. Malang. 2007.

[2] Purba, R. Memahami Asuransi di Indonesia. PT. Pustaka Binaman Presindo. Jakarta.1995.

[3] Haberman S. Decrement Tables and The Measurement of Morbidity. Journal of the Institute of Actuaries. Vol.110. pp. 361-381. 1983.

[4] Pitacco, Ermanno. Actuarial Models For Pricing Disability Benefits: Towards A Unifying Approach. Piazzela Europa 1, 34127. Trieste. Universita degli studi. Italy. 1994.

[5] Konetzka. Long Term Care Insurance. Journal vol. 3. No. 18. pages 152-159. Reliability Engineering And System Safety. Canada. 2014.

[6] Meira-Machado, L. Uña-Álvarez, J. Cadarso-Suárez, C. and Andersen, P.K. NIH Public Access. Multi-state Model for the Analysis of Time-to Event Data, Stat Methods Med Res. 18:195-222. 2009.

NURMAULIA NINGSIH $\quad$ : Jurusan Matematika FMIPA UNTAN, Pontianak nurmaulianingsih@student.untan.ac.id

NEVA SATYAHADEWI $\quad$ : Jurusan Matematika FMIPA UNTAN, Pontianak neva.satya@math.untan.ac.id

HENDRA PERDANA : Jurusan Matematika FMIPA UNTAN, Pontianak hendra.perdana@math.untan.ac.id 